\title{
Assessment of the rarity and conservation status of the Colombian endemic brown hairy dwarf porcupine Coendou vestitus
}

\author{
María M. Torres-Martínez, Héctor E. Ramírez-Chaves \\ Elim A. Noguera - URBano and Fernando C. Passos
}

\begin{abstract}
The brown hairy dwarf porcupine Coendou vestitus is a poorly studied Andean species endemic to Colombia. Its current Red List category is contradictory: globally it is categorized as Data Deficient but in Colombia it is categorized as Vulnerable. This contradiction has limited the implementation of conservation programmes. We evaluate the level of rarity of the species and provide consolidated information for a new assessment of its Red List status. We reviewed literature, photographs, and voucher specimens in natural history collections. Using the confirmed records, we estimated the extent of occurrence (EOO) based on the minimum convex polygon and the area of occupancy (AOO) summing the area of grid squares occupied by the species. We found that $C$. vestitus is very rare, with a small range, low estimated population density, occurrence in only one habitat type and small body size. The species has an EOO of $3,323 \mathrm{~km}^{2}$ and an AOO of $24 \mathrm{~km}^{2}$, based on six confirmed localities, all on the western slopes of the Eastern Cordillera, in the central Andean region of Colombia. Based on the species' rarity, restricted distribution, and threats to its natural habitat, we recommend its categorization as Endangered on the IUCN Red List. This will help delineate research and conservation efforts for this porcupine, which has a highly restricted range and inhabits the threatened Andean forest.
\end{abstract}

Keywords Andes, Coendou vestitus, Colombia, Endangered, porcupine, threat category, voucher specimen

\footnotetext{
María M. Torres-Martínez (Corresponding author, (D) orcid.org/0000-00025892-0788) Programa de Pós-graduação em Ecologia e Conservação, Laboratório de Biodiversidade, Conservação e Ecologia de Animais Silvestres, Universidade Federal do Paraná, Setor de Ciências Biológicas, Postal box 19031, CEP 81531-990, Curitiba, Brazil

E-mail canasmarianita@gmail.com

Héctor E. Ramírez-Chaves ([D orcid.org/0000-0002-2454-9482) Departamento de Ciencias Biológicas, Facultad de Ciencias Exactas y Naturales, and Centro de Museos, Museo de Historia Natural, Universidad de Caldas, Manizales, Colombia

Elkin A. Noguera-Urbano (1D orcid.org/0000-0002-4391-4852) Instituto de Investigación de Recursos Biológicos, Alexander von Humboldt, Bogotá, Colombia

Fernando C. Passos (D orcid.org/0000-0002-8994-3130) Programa de Pósgraduação em Ecologia e Conservação, Laboratório de Biodiversidade, Conservação e Ecologia de Animais Silvestres, Universidade Federal do Paraná, Curitiba, Brazil

Received 7 May 2019. Revision requested 18 June 2019.

Accepted 16 August 2019. First published online 17 November 2020.
}

\section{Introduction}

The brown hairy dwarf porcupine Coendou vestitus is 1 one of the rarest of the seven species of porcupines (genus Coendou) that occur in Colombia (Ramírez-Chaves et al., 2016). It is a small species (head-body length 330$370 \mathrm{~mm}$ ), characterized by having three types of fur: long dorsal fur, bicolored defensive fur, and bristles (Voss, 2015). Since its description more than a century ago (Thomas, 1899), it has been recorded from only six localities. This species is considered endemic to both sides of the Eastern Cordillera in the Colombian Andes, which is a complex ecosystem with topographical and biological diversity and high levels of endemism (Olson \& Dinerstein, 2002; Armenteras et al., 2003; Sánchez-Cuervo et al., 2012). Andean ecosystems are a global conservation priority as only $25 \%$ of their original extent remains (Armenteras et al., 2003).

Although C. vestitus is considered rare (Ramírez-Chaves et al., 2016), this condition has not been evaluated, and it has been suggested based only on the absence of data and the paucity of voucher specimens. Information on the ecology, genetics, natural history and conservation status of the species is also scarce, and in the case of the latter, contradictory. This porcupine is categorized as Data Deficient on the IUCN Red List (Weksler et al., 2016), with the assessment considering the presence of the species from only two localities, although in the same assessment three localities were mentioned. Nationally, the species has been categorized as Vulnerable based on its reduced geographical range as a result of habitat loss and fragmentation (Amori \& Gippoliti, 2003; Alberico \& Moreno, 2006; MADS, 2017). Currently, it is the only porcupine species categorized as threatened in Colombia (Alberico \& Moreno, 2006). Here, based on available literature, specimens in natural history museums and collections, and data from recent records, we evaluate the level of rarity of the species and reassess its conservation status.

\section{Methods}

\section{Assessing rarity}

To evaluate the rarity of the species we followed the criteria of Yu \& Dobson (2000), based on four characteristics: 
(1) local population density, (2) range, (3) the number of habitat types in which the species occurs and (4) body size. In addition, we suggest factors that may have determined the rarity category of this species. As the species population density has not been assessed, we documented the number of records per year since the species description. We consider the population density to be low if the number of records evaluated is $<_{1}$ for each 10-year interval (there are c. 10,000 records of mammals in databases for Cundinamarca, the department in which $C$. vestitus has been historically recorded). We also estimated the species range and related this to the rarity level using the extent of occurrence (EOO) and area of occupancy (AOO). We calculated the EOO using the minimum convex polygon (linking the known points of occurrence for the species), and the $\mathrm{AOO}$ by summing the area of grid squares in which the species is known (using grid squares of $2 \mathrm{~km}^{2}$ as recommended in IUCN, 2010) in GeoCAT (Bachman et al., 2011). For this we used data from six confirmed localities. Three of these are voucher specimens housed at Colombian collections and the other three are photographic records (Table 1). The photographs showed characters used to differentiate C. vestitus from other species in this genus: dorsal pelage with long blackish fur that partially or completely conceals defensive quills, and bicoloured bristle-quills (Voss \& da Silva, 2001; Voss, 2015; Plate 1). We excluded the record ICN 3505 from our analyses because the specimen was transported from another locality in the western part of the Eastern Cordillera; the location on the label of the specimen is in a market area (Alberico \& Moreno, 2006).

We also considered the number of habitats occupied by the species. For this, we overlaid the EOO on the ecoregions of Colombia, following the classification of terrestrial ecoregions (Olson et al., 2001). We evaluated body size based on information from the labels of the reviewed voucher specimens and from the literature (Voss, 2015; Ramírez-Chaves et al., 2016), and compared this trait with other species of Coendou.

\section{Conservation status}

To reassess the species conservation status, we used information on the level of rarity, EOO and AOO (IUCN, 2012). We included the level of rarity and the ecoregions the species inhabits to infer the conservation status of the species because of the absence of information on other factors that can influence the AOO, such as biotic interactions (predation, competition) and landscape (connectivity and shelter) (Bernard et al., 2013). We also examined whether the $\mathrm{EOO}$ or $\mathrm{AOO}$ of $C$. vestitus overlaps with protected areas, by using the protected areas layer for Colombia (October 2018; SINAP, 2018), and evaluated the per cent of forest area that remained unchanged during 2016-2017 within the polygon of the species range (IDEAM, 2018). To evaluate overlap of the AOO and EOO with protected areas, we estimated the extent $\left(\mathrm{km}^{2}\right)$ of protected areas inside the EOO polygon using as a limit the elevational range of the species, and determined the number of confirmed localities inside protected areas.

\section{Results}

Rarity Our findings indicate that $C$. vestitus matches the criteria of an extremely rare species (Category $\mathrm{H}$; $\mathrm{Yu} \&$ Dobson, 2000), based on all four factors evaluated.

Population density From the description of C. vestitus to the present, we found only 12 voucher specimens and photographs of three living specimens. Three records had no precise locality information. The records date from the species description in $\mathbf{1 8 8 9}$ to photographic records from Cundinamarca in 2018 (Plate 1, Table 1). The scarcity of records suggests a low population density, considering that several biological expeditions have visited the area in which the species occurs (Cundinamarca is the Department in which Bogotá, the capital of Colombia and home of the main Colombian academic institutions, is located).

Range It has been suggested that the elevational range of C. vestitus is $1,300-2,600 \mathrm{~m}$ (Barthelmess, 2016), 250-2,000 m (Alberico et al., 1999) and 600-1,440 m (Ramírez-Chaves et al., 2016). However, based on the information from confirmed localities, and discarding a dubious record from Villavicencio, the elevational range appears to be from 1,250 $\mathrm{m}$ (Cundinamarca, Quipile) to 2,600 m (Cundinamarca, Chicaque). The estimated area of the species range is based on only six confirmed localities (Table 1, Fig. 1), with an estimated EOO of $3,323 \mathrm{~km}^{2}$ and an AOO of $24 \mathrm{~km}^{2}$.

Number of habitat types in which the species occurs Overlaying the EOO on the terrestrial ecoregions map indicated that the species only occurs in tropical moist broadleaf forest (Olson et al., 2001). This ecoregion corresponds to the highly threatened sub-Andean and Andean forests.

Body size The adult body size of C. vestitus (total length of head and body $330-370 \mathrm{~mm}$ ) is within the range observed for small Coendou species (C. insidiosus $310-350 \mathrm{~mm}$; $C$. nycthemera 290-380 mm; C. pruinosus 320-380 mm; C. rufescens $340-410 \mathrm{~mm}$; C. melanurus $330-435 \mathrm{~mm}$; C. quichua 330-440 mm; C. speratus $330-440 \mathrm{~mm}$; C. spinosus $285-470$ $\mathrm{mm}$; C. bicolor $450-500 \mathrm{~mm}$; C. prehensilis $400-530 \mathrm{~mm}$ ), being the third smallest species of the genus after C. ichillus $(260-290 \mathrm{~mm})$ and C. roosmalenorum $(290 \mathrm{~mm})$. Coendou vestitus has, however, a considerably shorter tail than the latter species. 
TABLE 1 Records of Coendou vestitus in Colombia. Records from six confirmed localities were used in the analyses; one record (ICN 3505) was excluded.

\begin{tabular}{|c|c|c|c|c|}
\hline Record $^{1}$ & Locality & $\begin{array}{l}\text { Altitude } \\
(\mathrm{m})\end{array}$ & $\begin{array}{l}\text { Latitude, } \\
\text { longitude }\end{array}$ & Sources \& comments \\
\hline IAvH 7956; MLS 753 & Boyacá, Villa de Leyva & 2,100 & $\begin{array}{l}5^{\circ} 37^{\prime} 59^{\prime \prime} \mathrm{N} \\
73^{\circ} 31^{\prime} 32^{\prime \prime} \mathrm{W}\end{array}$ & Weksler et al. (2016) \\
\hline AMNH 70529 & Cundinamarca, Quipile & 1,250 & $\begin{array}{l}4^{\circ} 44^{\prime} 50^{\prime \prime} \mathrm{N} \\
74^{\circ} 31^{\prime} 59^{\prime \prime} \mathrm{W}\end{array}$ & $\begin{array}{l}\text { Voss \& da Silva (2001), } \\
\text { Voss }(2011,2015)\end{array}$ \\
\hline $\begin{array}{c}\text { AMNH 70596, 71359; BMNH } \\
\text { 24.2.21.2; MNHN 1929.631, } \\
\text { 1929.632; USNM } 240035\end{array}$ & $\begin{array}{l}\text { Cundinamarca, San Juan } \\
\text { de Rio Seco }\end{array}$ & 1,440 & $\begin{array}{l}4^{\circ} 51^{\prime} 4^{\prime \prime} \mathrm{N} \\
74^{\circ} 38^{\prime} 1^{\prime \prime} \mathrm{W}\end{array}$ & $\begin{array}{l}\text { Voss \& da Silva (2001), } \\
\text { Voss }(2011,2015)\end{array}$ \\
\hline Photograph & $\begin{array}{l}\text { Cundinamarca, Bogotá, } \\
\text { Parque Natural Chicaque }\end{array}$ & 2,625 & $\begin{array}{l}4^{\circ} 36^{\prime} 19.3^{\prime \prime} \mathrm{N} \\
74^{\circ} 18^{\prime} 19.8^{\prime \prime} \mathrm{W}\end{array}$ & 7 Oct. 2012, Pedro Pulido \\
\hline Photograph & $\begin{array}{l}\text { Cundinamarca, Ubaté, } \\
\text { vereda Volcán }\end{array}$ & 2,556 & $\begin{array}{l}5^{\circ} 20^{\prime} 14.72^{\prime \prime} \mathrm{N} \\
73^{\circ} 49^{\prime} 57.16^{\prime \prime} \mathrm{W}\end{array}$ & $\begin{array}{l}7 \text { Sep. } 2018 \text { by a local environmental } \\
\text { entity (Corporación Autonóma } \\
\text { Regional), La Villa (2018) }\end{array}$ \\
\hline Photograph & $\begin{array}{l}\text { Cundinamarca, Tena, } \\
\text { Laguna Pedro Palo }\end{array}$ & 2,080 & $\begin{array}{l}4^{\circ} 40^{\prime} 49^{\prime \prime} \mathrm{N} \\
74^{\circ} 23^{\prime} 24.3^{\prime \prime} \mathrm{W}\end{array}$ & $\begin{array}{l}25 \text { June } 2018 \text { by Sergio Chaparro } \\
\text { Herrera (Plate 1) }\end{array}$ \\
\hline ICN 3505 & Meta, Villavicencio & 610 & $\begin{array}{l}4^{\circ} 10^{\prime} 0^{\prime \prime} \mathrm{N} \\
73^{\circ} 39^{\prime} 0^{\prime \prime} \mathrm{W}\end{array}$ & $\begin{array}{l}\text { Alberico et al. (1999), } \\
\text { Ramírez-Chaves et al. (2016); } \\
\text { label indicates it was kept captive, } \\
\text { illegally }\end{array}$ \\
\hline MLS 249 & Cundinamarca & & No precise locality & \\
\hline MLS 640 & Cundinamarca & & No precise locality & \\
\hline BMNH 54.6.26.1 & Colombia & & No precise locality & Holotype \\
\hline
\end{tabular}

${ }^{1} \mathrm{IAvH}$, Instituto de Investigaciones Biológicas Alexander von Humboldt; MLS, Museo de La Salle; AMNH, American Museum of Natural History; BMNH, British Museum of Natural History; MNHN, Muséum National d'Histoire Naturelle; USNM, National Museum of Natural History; ICN, Instituto de Ciencias Naturales, Universidad Nacional de Colombia.

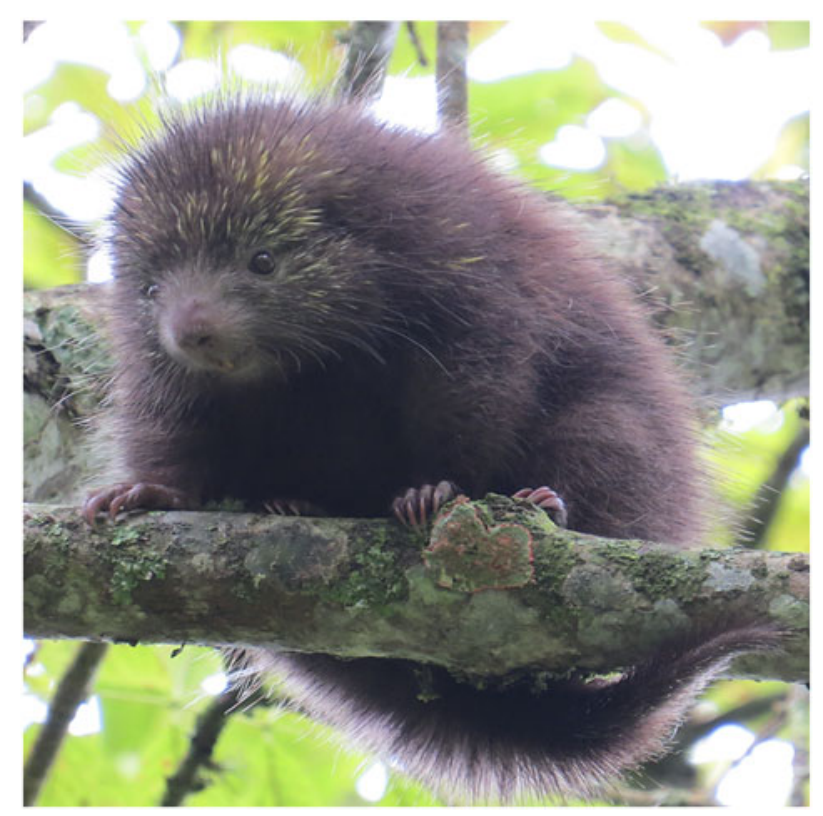

Plate 1 Photographic record (June 2018) of Coendou vestitus from Pedro Palo, Tena, Colombia (Table 1). Photo: Sergio Chaparro.

Conservation status We found only two localities (of the six confirmed) within conservation areas $(33.3 \%$ of the occurrences), although the EOO polygon intersected with 35 protected areas, managed by two institutions (Corporación Autónoma Regional and Parques Naturales
Nacionales de Colombia). Specifically, these 35 areas include one Soil Conservation District, five Regional Protected Forest Reserves, eight Regional Integrated Management Districts, and 21 Natural Civil Society Reserves (UNEPWCMC, 2019). The portions of the protected areas within the EOO polygon have a total area of $1,025 \mathrm{~km}^{2}$, with $1,298 \mathrm{~km}^{2}$ of the EOO not lying within protected areas (Fig. 1a). When overlapping the forest coverage with the EOO polygon, the forest coverage during 2016-2017 was $219 \mathrm{~km}^{2}(6.6 \%)$. Considering the species' range and its rarity, we recommend that C. vestitus is recategorized from Data Deficient to Endangered based on the following criteria: (1) Bib(iii,iv,v) and $\mathrm{B}_{2} \mathrm{~b}$ (iii,iv,v): with an $\mathrm{EOO}$ of $<5,000 \mathrm{~km}^{2}(\mathrm{~B} 1)$ and continuing decline inferred (b) in extent and/or quality of habitat (iii), number of locations or subpopulations (iv) and the number of mature individuals (v), and similarly with an AOO $<500 \mathrm{~km}^{2}$ (B2); (2) C2b: population size estimated to number $<2,500$ mature individuals with a continuing decline, observed, projected, or inferred (C), and, continuing decline, observed, projected or inferred, in numbers of mature individuals, and extreme fluctuations in number of mature individuals $(2 \mathrm{~b})$.

\section{Discussion}

Our recommendation to categorize $C$. vestitus as Endangered follows IUCN (2012) recommendations to assess poorly 

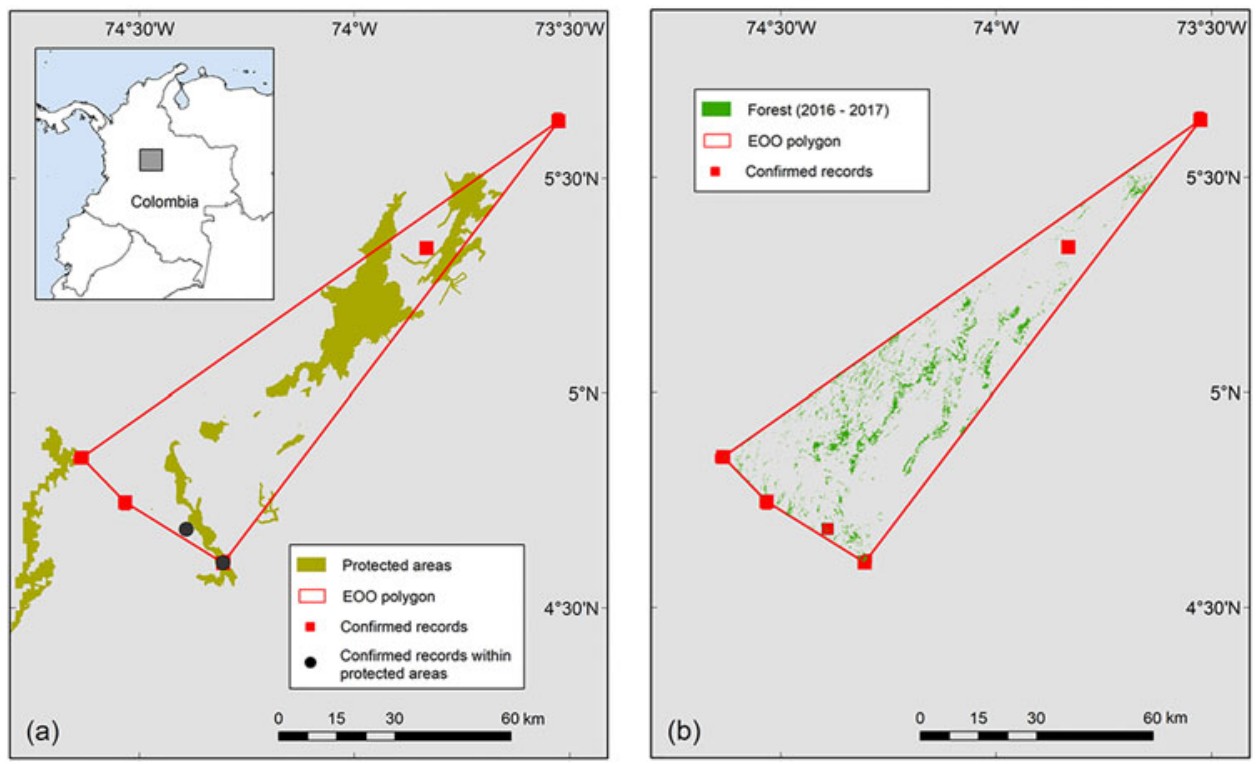

FIG. 1 Extent of occurrence (EOO) of Coendou vestitus, with (a) protected areas within the EOO, indicating the two records in protected areas, and (b) forest coverage in 2016-2017. known taxa based on information on inferred habitat loss and restricted distribution, to avoid assigning a Data Deficient category. The current IUCN information (Weksler et al., 2016) is incomplete (with AOO and EOO unknown) because it includes data for only from two localities (Voss, 2015). The periodic re-evaluation of a species' Red List status is an important tool for the planning, monitoring and management of biodiversity conservation (Hoffmann et al., 2010; Angulo et al., 2019).

Besides being an endemic and rare species, our findings confirm that $C$. vestitus is restricted to an ecosystem in which habitat is being lost and there are continuing threats from anthropogenic transformation (Thiollay, 1996; Armenteras et al., 2003; Angulo et al., 2019). The Eastern Cordillera comprises $40 \%$ of Andean ecosystems, but only $27 \%$ of its original vegetation cover remains. Although this region is characterized by high species richness and endemism it is one of the least known and least protected ecosystems (Armenteras et al., 2003; Rodríguez-Erazo et al., 2010). Habitat loss affects the persistence of small mammals, which play important ecological roles, for example as seed dispersers of pioneer species, and in trophic and predator-prey relationships (Decher, 1997; Brose et al., 2006; Lima et al., 2010; Tsai et al., 2016).

Although C. vestitus has previously been considered a rare species because of the scarcity of records (RamírezChaves et al., 2016), there are other reasons for it to be considered rare (Cofré \& Marquet, 1999). Although other porcupines in Colombia are known from fewer specimens (e.g. C. ichillus), they are not endemic to the country, having a wider distribution (Voss, 2015). Our confirmation of rarity is based on a combination of apparent low local population density, a small range, occurrence in only one habitat type, and small body size.

In general, small-sized species of Coendou (e.g. C. ichillus, C. roosmalenorum and C. vestitus) have more restricted distributions in the northern part of South America compared to the larger species that have only one type of quills in adulthood (e.g. C. prehensilis and C. bicolor; Voss, 2015). The rarity of $C$. vestitus is perhaps associated with homoplastic functional traits such as the presence of three types of hairs in adulthood (i.e. with less protection against predators than species with a body fully-covered by quills) (Voss et al., 2013) and small body size (Gaston \& Blackburn, 1995; Yu \& Dobson, 2000). Several species of African small mammals have been categorized as rare or Vulnerable (Schlitter, 1989; Decher, 1997) because their size could influence predator-prey relationships (Brose et al., 2006; Tsai et al., 2016). In this context, additional morphological characters may confer an adaptive advantage to large Coendou species: a body mostly covered by quills in adulthood provides a possible advantage against predators (Scharf et al., 2000; Speed \& Ruxton, 2005), the swollen nasofrontal sinuses protect the brain, and a larger tail facilitates arboreal locomotion, as observed in C. bicolor and C. prehensilis (Voss et al., 2013; Voss, 2015). The morphological and/or evolutionary reasons for the restricted range of small-sized Coendou are, however, as yet unclear, and require further research.

Although 106 genera, 333 species and 61 subspecies of rodents are considered threatened and have high endemism (Ceballos \& Brown, 1995; Amori \& Gippoliti, 2001, 2003, IUCN, 2020) a relatively lower per cent of rodents are categorized as threatened compared to other mammalian groups (Ceballos \& Brown, 1995; IUCN, 1997; Amori \& Gippoliti, 2001). No Coendou species are as yet categorized as threatened (IUCN, 2017): six are categorized as Data Deficient, including C. vestitus, and eight as Least Concern.

The only locations of $C$. vestitus within protected areas are in the $2.44 \mathrm{~km}^{2}$ Nature Reserve Parque Natural Chicaque and the $0.45 \mathrm{~km}^{2}$ Natural Civil Society Reserve Tenasuca de Pedro Palo, which together correspond to 
only $0.08 \%$ of the species' range (Fig. 1a). In addition to the small EOO, the area of the 35 protected areas within the EOO is small (a mean of $29 \mathrm{~km}^{2}$ per protected area). The area surrounding the EOO is severely affected by extensive commercial plantations and urban settlements, with only c. $50 \%$ of the ecoregion unaffected (Armenteras et al., 2003; Sánchez-Cuervo et al., 2012; Angulo et al., 2019). This limits connectivity (Bright, 1993), which is important for the persistence of a species (Passos et al., 2016). Maintenance, extension or connection of protected areas, connecting the relict habitats, could help to protect C. vestitus (Cofré \& Marquet, 1999; Amori \& Gippoliti, 2003; Armenteras et al., 2003).

Conservation strategies and financial resources need to be established for threatened and endemic species and for species with restricted distributions (Cofré \& Marquet, 1999; Isaac et al., 2007). However, for mammals most monitoring and conservation efforts are directed at large or charismatic species. Less attention has been directed at rodents, even though the group has a high extinction rate (Amori \& Gippoliti, 2001, 2003; Armenteras et al., 2003). Prioritizing the conservation of $C$. vestitus has the potential to contribute to the protection of the ecosystems in which it occurs and of co-occurring species. We recommend that national agencies prioritize this porcupine species, together with other species in urgent need of monitoring.

Porcupines remain a poorly known group, both at national and Neotropical levels (Voss, 2011). Knowledge of the ecology of $C$. vestitus is mostly based on inference from other porcupine species (e.g. Alberico \& Moreno, 2006; Weksler et al., 2016). Our compilation of information on C. vestitus highlights the need for further fieldwork and data collection. Nevertheless, threats to porcupines are evident, in particular loss of habitat, illegal trade, road-kills, and hunting for consumption (de Freitas et al., 2013; Racero-Casarrubia et al., 2016). In Colombia, illegal captivity has also been documented (on a voucher specimen label; Table 1) as a threat to the species. Our compilation of data and our findings form the basis for further research and for the establishment of conservation strategies and future evaluations of the distribution and conservation status of $C$. vestitus.

Acknowledgements We thank Hugo López (Instituto de Ciencias Naturales, Universidad Nacional de Colombia) and Cristian Cruz Rodríguez (Museo de La Salle) for allowing us to review specimens under their care; Luiz H. Varzinczak for useful comments on the text; Pedro Pulido, Sergio Chaparro and Carlos Aya for sharing records and photographs; and Mario Ernesto Jijón Palma for help with the map. MMTM thanks Coordenação de Aperfeiçoamento de Pessoal de Nível Superior, Brazil (Finance Code 001) for support. HERC thanks Instituto de Investigación de Recursos Biológicos Alexander von Humboldt (Andrés M. Cuervo and María López Rodríguez) for access to voucher specimens, and The Rufford Small Grants (Grants 23710-1 and 29491-2), the Universidad de Caldas (projects 0743919 and 0223418), and the Science and Scholarship Committee of the Field Museum of Natural History, Chicago, for support. FCP thanks the Brazilian National Council for Scientific and Technological Development (CNPq) (Grant 307303/2017-9).
Author contributions Project design: MMT-M, HER-C; data collection: MMT-M, HER-C, EAN-U; evaluation of rarity and threatened status: MMT-M, FCP; writing: MMT-M, HER-C.

\section{Conflicts of interest None.}

Ethical standards This research abided by the Oryx guidelines on ethical standards.

\section{References}

Alberico, M. \& Moreno, J.G. (2006) Puerco espín pardo Coendou vestitus. In Libro Rojo de los Mamíferos de Colombia. Serie Libros Rojos de Especies Amenazadas de Colombia (eds J.V. RodríguezMahecha, M. Alberico, F. Trujillo \& J. Jorgenson), pp. 293-295. Conservación Internacional Colombia, Ministerio de Ambiente, Vivienda y Desarrollo Territorial, Bogotá, Colombia.

Alberico, M., Rojas-Díaz, V. \& Moreno, J.G. (1999) Aporte sobre la taxonomía y distribución de los puercosespines (Rodentia: Erethizontidae) en Colombia. Revista de la Academia Colombiana de Ciencias Exactas, Físicas y Naturales, 23, 595-612.

Amori, G. \& Gippoliti, S. (2001) Identifying priority ecoregions for rodent conservation at the genus level. Oryx, 35, 158-165.

Amori, G. \& Gippoliti, S. (2003) A higher-taxon approach to rodent conservation priorities for the 21st century. Animal Biodiversity and Conservation, 26, 1-18.

Angulo, A., von May, R. \& Icochea, J. (2019) A reassessment of the extinction risk of the Critically Endangered Oxapampa poison frog Ameerega planipaleae (Dendrobatidae). Oryx, 53, 557-560.

Armenteras, D., Gast, F. \& Villareal, H. (2003) Andean forest fragmentation and the representativeness of protected natural areas in the eastern Andes, Colombia. Biological Conservation, 113, 245-256.

Bachman, S., Moat, J., Hill, A.W., de la Torre, J. \& Scott, B. (2011) Supporting Red List threat assessments with GeoCAT: geospatial conservation assessment tool. ZooKeys, 150, 117-126.

Barthelmess, E.L. (2016) Family Erethizontidae. In Handbook of Mammals of the World. Vol. 6. Lagomorphs and Rodents: Part 1 (eds D.E. Wilson, T.E. Lacher \& R.A. Mittermeier), pp. 372-397. Lynx, Barcelona, Spain.

Bernard, E., Nascimento, J.L. \& Aguiar, LM.S. (2013) Flagging a species as threatened: the case of Eptesicus taddeii, an endemic bat from the Brazilian Atlantic Forest. Biota Neotropical, 13, 314-318.

BRIGHT, P.W. (1993) Habitat fragmentation-problems and predictions for British mammals. Mammal Review, 23, 101-111.

Brose, U., Jonsson, T., Berlow, E.L., Warren, P., BanasekRichter, C., Bersier, L., Blanchard, J.L. et al. (2006) Consumerresource body-size relationships in natural food webs. Ecology, 97, 2411-2417.

Ceballos, G. \& Brown, J.H. (1995) Global patterns of mammalian diversity, endemism, and endangerment. Conservation Biology, 9, 559-568.

Cofré, H. \& Marquet, P.A. (1999) Conservation status, rarity, and geographic priorities for conservation of Chilean mammals: an assessment. Biological Conservation, 88, 53-68.

DECHER, J. (1997) Conservation, small mammals, and the future of sacred Groves in West Africa. Biodiversity and Conservation, 6, 1007-1026.

de Freitas, M.A., de Franç, D.P.F. \& Veríssimo, D. (2013) First record of the bicoloured-spined porcupine Coendou bicolor (Tschudi, 1844) for Brazil. Check List (Luis Felipe Toledo), 9, 94-96.

Gaston, K.J. \& Blackburn, T.M. (1995) Rarity and body size: some cautionary remarks. Conservation Biology, 9, 210-213.

Hoffmann, M., Hilton-Taylor, C., Angulo, A., Böhm, M., Brooks, T.M., Butchart, S.H.M. et al. (2010) The impact of 
conservation on the status of the world's vertebrates. Science, 330, 1503-1509.

IDEAM (2018) Análisis Bosque - No Bosque (2016.2017). Subdirección de Ecosistemas e Información Ambiental. Grupo de Bosques. Proyecto Sistema de Monitoreo de Bosques y Carbono, Bogotá, Colombia.

Isaac, N.J.B., Turvey, S.T., Collen, B., Waterman, C., Baillie, J.E.M. (2007) Mammals on the EDGE: conservation priorities based on threat and phylogeny. PLOS ONE, 3, e296.

IUCN (1997) 1996 IUCN Red List of Threatened Animals. World Conservation Union, Gland, Switzerland.

IUCN Standards and Petitions Subcommittee (2010) Guidelines for using the IUCN Red List Categories and Criteria. Version 8.1. IUCN, Gland, Switzerland.

IUCN (2012) IUCN Red List Categories and Criteria. Version 3.1. 2nd edition. Gland, Switzerland and Cambridge, UK.

IUCN (2017) The IUCN Red List of Threatened Species. Version 2017-2. iucnredlist.org [accessed 10 October 2018].

IUCN (2020) Numbers of Species in each IUCN Red List Category in each Major Animal Taxonomic Group (Class, Order). iucnredlist. org/resources/summary-statistics\#Summary\%20Tables [accessed 3 April 2020].

La Villa (2018) CAR Rescata Puercoespín en Vereda Volcán 2 en Ubaté. Periódico Regional 'La Villa'. lavilla.com.co/portal/2018/o9/ o7/car-rescata-puercoespiin-en-vereda-volcan-2-en-ubate [accessed 3 April 2019].

Lima, R.B.S., Oliveira, P.A. \& Chiarello, A.G. (2010) Diet of the thin-spined porcupine (Chaetomys subspinosus), an Atlantic forest endemic threatened with extinction in south eastern Brazil. Mammalian Biology, 75, 538-546.

MADS (Ministerio del Ambiente y Desarrollo Sostenible) (2017) Resolución No. 1912, 'Por la cual se establece el listado de las especies silvestres amenazadas de la diversidad biológica colombiana continental y marino costera que se encuentran en el territorio nacional, y se dictan otras disposiciones'. Bogotá, Colombia, 15 September 2017. minambiente.gov.co/images/ normativa/app/resoluciones/75-res\%201912\%2ode\%202017.pdf [accessed 5 February 2019].

Olson, D.M. \& Dinerstein, E. (2002) The global 200: priority ecoregions for global conservation. Annals of the Missouri Botanical Garden, 89, 199-224.

Olson, D.M., Dinerstein, E., Wikramanayake, E.D., Burgess, N.D., Powell, G.V.N., Underwood, E.C. et al. (2001) Terrestrial ecoregions of the world: a new map of life on Earth. BioOne, 51, 933-938.

Passos, F.C., Mello, M.C.H., Isati-Catalá, E., Mello, R.C., Bernardi, I.P., VArZINCZAK, L.H. et al. (2016) The Vulnerable giant anteater Myrmecophaga tridactyla: new records from the Atlantic Forest highlands and an overview of its occurrence in protected areas in Brazil. Oryx, 51, 564-566.

Racero-Casarrubia, J., Chacón-Pacheco, J., Humanez-López, E. \& Ramírez-Chaves, H.E. (2016) Registros recientes de los puercoespines, género Coendou (Mammalia: Erethizontidae) para el departamento de Córdoba, Colombia. Biota Colombiana, 17, 137-142.

Ramírez-Chaves, H.E., Suárez-Castro, A.F., MoralesMartínez, D.M. \& Vallejo-Pareja, M.C. (2016) Richness and distribution of porcupines (Erethizontidae: Coendou) from Colombia. Mammalia, 80, 181-191.
Rodríguez-Eraso, N., Pabón-Caicedo, J.D., Bernal-Suárez, N.R. \& Martínez-Collantes, J. (2010) Cambio Climático y su Relación con el Uso del Suelo en los Andes Colombianos. Instituto de Investigación de Recursos Biológicos Alexander von Humboldt, Universidad Nacional de Colombia y Departamento Administrativo de Ciencia, Tecnología e Innovación, Bogotá, Colombia.

Sánchez-Cuervo, A.M., Aide, T.M., Clark, M.L. \& Etter, A. (2012) Land cover change in Colombia: surprising forest recovery trends between 2001 and 2010. PLOS ONE, 7, e43943.

Scharf, F.S., Juanes, F. \& Rountree, R.A. (2000) Predator size-prey size relationships of marine fish predators: interspecific variation and effects of ontogeny and body size on trophic-niche breadth. Marine Ecology Progress Series, 208, 229-248.

Schlitter, D.A. (1989) African rodents of special concern: a preliminary assessment. In Rodents-A World Survey of Species of Conservation Concern. Occasional Papers of the IUCN Species Survival Commission (ed. W.Z. Lidicker, Jr.), pp. 33-39. IUCN/SSC Gland, Switzerland.

SINAP (2018) Datos Abiertos, Información Geográfica. Sistema Nacional de Áreas Protegidas de Colombia-SINAP. Parques Nacionales Naturales de Colombia. parquesnacionales.gov.co/portal/servicio-al-ciudadano/ datos-abiertos [accessed 10 October 2018].

Speed, M.P. \& Ruxton, G.D. (2005) Warning displays in spiny animals: one (more) evolutionary route to aposematism. Evolution, 59, 2499-2508.

Thiollay, J. (1996) Distributional patterns of raptors along altitudinal gradients in the northern Andes and effects of forest fragmentation. Journal of Tropical Ecology, 12, 535-560.

Thomas, O. (1899) Description of new Neotropical mammals. Annals and Magazine of Natural History, Series Zoology, 7, 278-288.

Tsai, C.-H., Hsien, C. \& Nakazawa, T. (2016) Predator-prey mass ratio revisited: does preference of relative prey body size depend on individual predator size? Functional Ecology, 30, 1979-1987.

UNEP-WCMC (2019) Protected Area Profile for Colombia from the World Database of Protected Areas, April 2019. Protected Planet. protectedplanet.net [accessed 11 April 2019].

Voss, R.S. (2011) Revisionary notes on Neotropical porcupines (Rodentia: Erethizontidae). 3. An annotated checklist of the species of Coendou lacepede, 1799. American Museum Novitates, 3720, 1-36.

Voss, R.S. (2015) Superfamily Erethizontoidea Bonaparte, 1845. In Mammals of South America. Volume 2. Rodents (eds J.L. Patton, U.F.J. Pardiñas \& G.D. D’Elía), pp. 786-805. The University of Chicago Press, Chicago, USA.

Voss, R.S. \& DA SILVA, M.N.F. (2001) Revisionary notes on neotropical porcupines (Rodentia, Erethizontidae). 2. A review of the Coendou vestitus group with descriptions of two new species from Amazonia. American Museum Novitates, 3351, 1-36.

Voss, R.S., Hubbard, C. \& Jansa, S.A. (2013) Phylogenetic relationships of new world porcupines (Rondentia, Erethizontidae): implications for taxonomy, morphological evolution, and biogeography. American Museum Novitates, 3769, 1-36.

Weksler, M., Anderson, R.P. \& Gómez-Laverde, M. (2016) Coendou vestitus. In The IUCN Red List of Threatened Species 2016: e.T20633A22213528. dx.doi.org/10.2305/IUCN.UK.2016-2.RLTS. T20633A22213528.en [accessed 20 July 2017].

Yu, J. \& Dobson, F.S. (200o) Seven forms of rarity in mammals. Journal of Biogeography, 27, 131-139. 